contains the numerical results arrived at, together with certain observations suggested by them. The tables given lend support to the following interpretation :-

"The predominance of green or blue-the colours of vegetation, the sky, and the sea-means that the poet is predominantly a poet of nature. If red and its synonyms are supreme, we may assume an absorbing interest in man and woman, for they are the colours of blood and of love, the two main pivots of human affairs, at all events in poetry. And where there is a predominance of black, white, and, I think I would add, yellowthe colours that are rare in the world, and the colour of golden impossibilities--there we shall find that the poet is singing with, as it were, closed eyes, intent on his own inner vision.

Although I cannot claim to have put this numerical test of colour-vision into a final shape, there can be little doubt that it possesses at least two uses in the precise study of literature. It is, first, an instrument for investigating a writer's personal psychology, by defining the nature of his asthetic colour-vision. When we have ascertained a writer's colour-formula and his colours of predilection, we can tell at a glance, simply and reliably, something about his view of the world which pages of description could only tell us with uncertainty. In the second place, it enables us to take a definite step in the attainment of a scientific rsthetic, by furnishing a means of comparative study. By its help we can trace the colours of the world as mirrored in literalure from age to age, from country to country, and in finer shades among the writers of a single group."

Another article in the Contemporary is of scientific interest: it is on "The Proposed Gigantic Model of the Earth," by Dr. A. R. Wallace. It may be remembered by our readers that M. Elisée Reclus has drawn up a scheme for constructing a terrestrial globe on a scale of one-hundred-thousandth the actual size, that is, $4 \mathrm{I} 8$ feet in diameter. Another globe would be required as a cover for the actual earth-model, so that the expense of such a duplex structure would be enormous. Dr. Wallace gives a qualified support to M. Reclus' proposal ; for he thinks only one globe should be constructed, showing all the great geographical features of the earth on its outer surface, while on the inner surface would be formed that strictly accurate model which M. Reclus considers would justify the expense of such a great work.

Miss Mary Kingsley contributes to the National an interesting account of her ascent of "The Throne of Thunder," or the Peak of Cameroons, the highest point on the western side of the African continent. Twenty-seven white men have reached the peak, and Miss Kingsley describes the twenty-eighth ascent, the second successful one from the south-east face. In the same review Mr. A. G. Boscawen, M.P., gives his impressions of Japan, and concludes his remarks with a few words about British commercial interests in the Far East. It is satisfactory to note his remarks on the advantages to be gained by the appointment of commercial and technical advisers to foreign Legations. He says :-

"And now I would suggest what I have suggested elsewhere, that the Government ought to give a helping hand by appointing a commercial attaché to the Legation at Tökyõ, who I feel sure would prove most useful at the present moment, when the Tapanese are friendly to us, and are certainly inclined to buy from us if we will only take the trouble to adapt our manufactures to their markets. Such an official, by keeping us constantly informed at home of what articles the Japanese require, would prevent a large portion of our trade from going to foreigners, especially to the Germans and Americans, who have for years taken far more trouble than we have to secure the goodwill of the Japanese."

A passing mention must suffice for the remaining articles of scientific interest in the magazines and reviews received. Sir Robert Ball writes on "The Scenery of the Moon," in the Strand Magazine, his description being illustrated by reproduc. tions from lunar photographs. Miss Agnes Giberne treats the well-worn theme of "The Far Distance of our Universe," in Chambers's Joumal, which also contains popular articles on the electric supply of London, jumping beans, and house-filies. Some suggestive points in connection with the evolution of anguage will be found in the article entitled "The Genesis of Expression," by M. L. Johnson, in the Westminster Reviezw. A well-illustrated paper on "The Evolution of the Trotting Horse," contributed by Mr. Hamilton Bushey to Scribner, is not without interest to scientific readers. Under the title "Through Scientific Doubt to Faith," the Quarterly Reviezw traces the mental history of Romanes, as evidenced by his own works, and in the lately published "Life and Letters," written and edited by his wife. The article is a complacent statement from the religious side. The Viscount Harberton writes on "Muzzling and the Prevention of Rabies" in the Humanitarian. Mr. P. C. Knapp brings forward evidence, in the Century against the view that nervous disorders are increasing, and shows that, without more evidence in its favour, the belief in the greater nervousness of Americans is an error. Finally, the Geographical Journal contains Mr. St. George Littledale's account of "A Journey across Tibet, from North to South, and West to Ladak," and Mr. Edward A. FitzGerald's paper on "The First Crossing of the Southern Alps of New Zealand." Attention may profitably be drawn to the maps which illustrate Mr. Littledale's journey, and to a new map of the Upper Kuyuni River, British Guiana, from a recent survey.

\section{THE METRIC SYSTEM IN THE UNITED STATES}

STRENUOUS efforts are being made by the American Metrological Society to secure the adoption of the Bill making the use of the metric system obligatory in the United States after a specified date. Letters have been sent to all who are interested in the question, soliciting their help and influence, and petitions are being numerousiy signed and sent in to Representatives. The Committee on Coinage, Weights and Measures, of the House, recently reported unanimously in favour of the Bill, and the introduction and conclusion of their interesting report are reprinted in Science, from which source the subjoined summary has been made.

For more than a generation after the construction of the constitution, the American people lived with no legal standard by which could be determined even the amount of metal which went into the coin that came from their mints. Gallatin procured from France a platinum kilogram and meter in 1821 , and from England a troy pound in I 827 , and in 1828 the latter was recognised as the standard for mint purposes by the following Act: :

"For the purpose of securing due conformity in weight of the coins of the United States to the provisions of this title, the brass troy pound weight procured by the Minister of the United States at London in the year eighteen hundred and twenty-seven for the use of the mint and now in custody of the mint at Philadelphia, shall be the standard troy pound of the mint of the United States, conformably to which the coinage thereof shall be regulated."

Meantime both the people and the Government were using such wejghts and measures as were nearest at hand, derived in the main from the English ancestry, but made by themselves without any authoritative standard for comparison, and as a consequence differing materially from each other. In I830 the Senate directed the Secretary of the Treasury to have a comparison made of the standards of weight and measure used at the principal custom houses of the United States, and report the same to the Senate. This was done, and large discrepancies and errors were found to exist. These discrepancies were nullifying and violating the provision of the Constitution which prescribes that "all duties, imposts and excises shall be uniform throughout the United States." Varying scales and varying measures inevitably produced varying rates of duty. The Treasury Department, therefore, in the exercise of its executive power and as a necessary incident and means to the execution of the law and the observance of the Constitution, adopted for the use of that Department the Troughton scale, then in the possession and use of the Coast Survey, as the unit of length, and the troy pound of the mint as the unit of weight. From the latter the avoirdupois pound was to be derived, assuming that there were 7000 grains in the pound avoirdupois to 5760 in the pound troy. For measures of capacity the wine gallon of $23 \mathrm{I}$ cubic inches, and the Winchester bushel of $215^{\circ} 42$ cubic inches, were adopted. This gave to the Treasury Department the basis of a system of weights and meastres to be used in its operations, and in order to promote the general adoption and use of the same throughout the country, Congress, in June I 836 , adopted the following joint resolution :

"That the Secretary of the Treasury be, and he hereby is, NO. I 385 , VOL. 5t] 
directed to cause a complete set of all the weights and measures adopted as standards, and now either made or in the progress of manufacture for the use of the several custom houses, and for other purposes, to be delivered to the Governor of each State in the Union, or such persons as he may appoint, for the use of the States, respectively, to the end that a uniform standard of weights and measures may be established throughout the Union."

In accordance with this resolution, sets of the weights and measures adopted for use in the custom houses were sent to the several States, and only in this indirect and inferential way have the customary weights and measures of the United States been legally recognised. By the Act of March 3, I88I, similar sets of standards were directed to be supplied to the varicus agricultural colleges which had received land grants from the United States at a cost not exceeding 200 dols. for each set. This law was complied with as best it could be under the limitation of cost prescribed.

Meantime the metric system had come into extensive use among other nations, and into almost universal use in the realm of exact science the world over. The Americans touched it at every turn in their commercial relations and scientific investigations. Uniformity in weights and measures throughout the world was urged not only by men of science, but by sagacious business men, seeking to keep pace with the rapidly growing tendencies to closer commercial and business relations among the nations resulting from the improved facilities of communication and transportation which had largely removed the barriers of space and distance. Hence in 1866 Congress, with the approval of the President, placed on the statute books the following law :

"AN ACT to authorise the use of the metric system of weights and measures.

"Be it enacted by the Senate and House of Representatives of the United States of America in Congress assembled, That from and after the passage of this Act it shall be lawful throughout the United States of America to employ the weights and measures of the metric system, and no contract or dealing, or pleading in any court, shall be deemed invalid or liable to objection because the weights or measures expressed or referred to therein are weights or measures of the metric system.

"Sec. 2. And be it further enacted, That the tables in the schedule hereto annexed shall be recognised in the construction of contracts, and in all leading proceedings, as establishing, in terms of the weights and measures now in use in the United States, the equivalents of the weights and measures expressed therein in terms of the metric system; and said tables may be lawfully used for computing, determining and expressing, in customary weights and measures, the weights and measures of the metric system."

To make this law of practical use the following joint resolution was adopted :

"JoinT RESOLUTION to enable the Secretary of the Treasury to furnish each State with one set of the standard weights and measures of the metric system.

"Be it resolved by the Senate and House of Representatives of the United States of America in Conoress assembled, That the Secretary of the Treasury be, and he is hereby authorised and directed to furnish to each State, to be delivered to the Governor thereof, one set of standard weights and measures of the metric system for the use of the State respectively."

By inadvertence, and without important legal significance, the resolutions providing for furnishing the standards became a law before the Act authorising the use of the system. In the same year Congress put it in the power of the Post-Office Department to make extensive use of metric weights in its operations. The law of that year was re-stated and re-enacted in 1872 , and now stands in the Revised Statutes in the following terms:

"The Postmaster-General shall furnish to the post-offices exchanging mails with foreign countries, and to such other offices as he may deem expedient, postal balances denominated in grams of the metric system, fifteen grams of which shall be the equivalent for postal purposes, of one-half ounce avoirdupois, and so on in progression."

The International Postal Convention of two years later, and which by subsequent renewals is now in force between the United States and fifty other nations, uses only metric weights and terms, and to-day the mail matter transported between America and other nations, even between the United States and England, is weighed and paid for entirely in terms of metric weights.

NO. I 38.5 , VOL. 547
Here legislation on the subject of weights and measures rested till I893. In the meantime important action was taken by the Executive Department of the Government. The progress of science, carrying with it the capability of more accurate observation and measurement, had disclosed the fact that the metric standards in use in different countries differed among themselves, and indicated that even the standards in the archives of France could be constructed with greater precision and accuracy, and preserved with greater safeguards against possible variation from influence of the elements or other forces. Hence France invited the other nations to join in an international Commission for the purpose of constructing a new metre as an international standard of length. America accepted the invitation, and was represented in the Commission, which met in 1870 , and continued its labours from time to time till they were finally consummated in the conclusion of a metric convention signed on May 20, I875, by the representatives of the following nations, viz. the United States, Germany, Austria-Hungary, Belgium, Brazil, Argentine Confederation, Denmark, Spain, France, Italy, Peru, Portugal, Russia, Sweden and Norway, Switzerland, Turkey, and Venezuela.

The first name signed to this convention is that of $\mathrm{E}$. B. Washburn, the United States Minister and Representative. The treaty provided for the establishment and maintenance, at the common expense of the contracting nations, of " a scientific and permanent international bureau of weights and measures, the location of which shall be Paris," to be conducted by "a general conference for weights and measures, to be composed of the delegates of all the contracting governments." Beyond the construction and custody of the international standards and the distribution to the several countries of copies thereof, it was expressly provided as to this conference by the terms of the treaty or convention that "it shall be its duty to discuss and initiate measures necessary for the dissemination and improvement of the metrical system." This convention was duly ratified by the Senate, and since that time the United States has been regularly represented in the International Conference, and has paid its proper proportion of the cost of maintaining the International Bureau of Weights and Measures. By the terms of the convention the privilege of acceding thereto and thus becoming a party to it was reserved to any nations desiring to avail themselves thereof, and accordingly the following nations have since become parties to the convention, viz. Servia in I879, Roumania in 1882 , Great Britain in 1884 , Japan in 1885 , and Mexico in I $89 \mathrm{I}$.

New standards were prepared with extreme care and accuracy, and duplicate copies thereof distributed to the several nations. Those for the United States were received with much ceremony at the White Ifouse, January 2, I890, by the President in the presence of members of his Cabinet and other distinguished gentlemen, and are now carefully guarded in a fire-proof room set apart for the safe-keeping of the standards of weights and measures in the Coast Survey building.

By formal order of the Secretary of the Treasury of April 5, I893, the metre and kilogram thus received and kept were recognised as "fundamental standards" from which the customary units of the yard and pound should be thereafter derived in accordance with the law of July $28, \mathrm{I} 866$.

Meantime Congress by Act of March 3, I893, established a standard scale for measurement of sheet and plate iron and steel, expressed in terms of both the customary and metric measures. "An Act to define and establish the units of electrical measure" was passed by the Fifty-third Congress and approved July 12, I894. It is based on the metrical system exclusively.

From this résumé of United States legislation on the subject of weights and measures it appears that a legal standard of weight has been established for use in the mint, but that beyond that the weights and measures in ordinary use rest on custom only with indirect legislative recognition; that the metric weights and measures are made legal by direct legislative permission, and that standards of both systems have been equally furnished by the Government to the several States; that the customary system has been adopted by the Treasury Department for use in the custom houses, but that the same Department by formal order has adopted the metric standards as the "fundamental standards" from which the measures of the customary system shall be derived. This presents a condition of legal complication and practical confusion that ought not to continue. The constitutional power vested in Congress should be exercised.

The Committee confessed that considerable temporary inconvenience would probably accompany the change, but they 
believed that this was greatly over-estimated, and that it would be of short duration. But whether the inconvenience be little or great, it must some time be encountered, and it will not be decreased by the increase of the population. It will be no easier for a hundred millions of people ten years hence to make the change than for seventy millions to-day. It is simply a question whether this generation shall accept the annoyance and inconvenience of the change largely for the benefit of the next, or shall the people of to-day selfishly consult only their own ease and impose on their children the double burden of learning and then discarding the present "brain-wasting system." The present generation must meet this test of selfishness or unselfishness, and answer to posterity for duty performed or neglected.

The Committee, after a careful consideration of the whole subject, unanimously reached the conclusion that the metric system of weights and measures should be put into exclusive use in the various Departments of the Government at such future date as shall allow adequate preparation for the change, and at the end of a fixed time thereafter that said system shall be recognised as the only legal system for general use. They, however, do not deem it wise at present to require a change in the methods of surveying the public lands, as this would in that respect destroy rather than promote uniformity.

The Committee deemed it prudent to enlarge the time for the proposed system to take effect to a date somewhat later than the date proposed in the Bill submitted, adopting for America about the average time deemed necessary by other nations. It is therefore recommended that the time for adoption in the Departments and operations of the Government, except in the completion of the survey of the public lands, be fixed for July I, 1898 , and that the adoption of the metric system for use in the nation at large be fixed as coincident with the dawn of the twentieth century, and that date be accordingly changed to January I, I90I, the first day of the new century.

The Bill reads as follows :-

"A Bill to fix the standard of weights and measures by the adoption of the metric system of weights and measures.

"Be it enaited by the Senate and House of Representatives of the United States of America in Congress assembled, That from and after the first day of July, eighteen hundred and ninety-eight, all the Departments of the ( Government of the United States, in transaction of all business requiring the use of weight and measurement, except in completing the survey of the public lands, shall employ and use only the weights and measures of the metric system.

"Sec. 2. That from and after the first day of January, nineteen nundred and one, the metric system of weights and measures shall be the only legal system of weights and measures recognised in the United States.

"Sec. 3. That the metric system of weights and measures herein referred to is that in which the ultimate standard of mass or weight is the international kilogram of the International Bureau of Weights and Measures, established in accordance with the convention of May twentieth, eighteen hundred and seventy-five, and the ultimate standard of length is the international metre of the same bureau, the national prototypes of which are kilogram numbered twenty and metre numbered twenty-seven, preserved in the archives of the office of standard weights and measures.

"Sec. 4. That the tables in the schedules annexed to the Bill authorising the use of the metric system of weights and measures passed July twenty-eighth, eighteen hundred and sixty-six, shall be the tables of equivalents which may be lawfully used for computing, determining and expressing the customary weights and measures in the weights and measures of the metric system."

\section{UNIVERSITY AND EDUCATIONAL INTE LLIGENCE.}

CAMBringe. - The first Smith's Prize is awarded to Mr. W. S. Adie, bracketed Senior Wrangier I 894 ; the second is divided between Mr. A. Y. G. Campbell, bracketed ninth Wrangler, and Mr. F. W. Lawrence, bracketed fourth Wrangler in the same year. All the prizemen are members of Trinity College.

Prof. Newton, F.R.S., has been reappointed one of the managers of the Balfour Studentships in Animal Morphology until June rgor.

The School of Medicine of the University of Toronto has been placed on the list of Colonial Schools recognised by the Special Board for Medicine.

No. 1385 , voL. 54]
The Council of the Senate recommend for affiliation to the University the Roman Catholic College of St. Edmund's, Ware, the successor since 1793 of the former English College at Douai.

On account of the increasing length of the practical examinations for the Natural Sciences Tripos, the Medical Board propose that the examinations for M.B. shall in future take place at a later date in the Michaelmas and Easter Terms. It is noted that a number of medical students are following with advantage the course for the ordinary B.A. degree, and a rearrangement of the dates of the examinations has become necessary to meet their case.

The next examination for the diploma in Agriculture will begin on July 6 , and last a week.

Sir William Priestley, the distinguished physician, has been elected parliamentary representative of the Universities of Edinburgh and St. Andrews.

THE City and Guilds of London Institute is inviting applications for the Professorship of Mechanical Engineering and Applied Mathematics at the Technical College, Finsbury, rendered vacant by the appointment of Prof. John Perry, F.R.S., to a Professorship at the Royal College of Science. Applications for the appointment should be addressed to the Honorary Secretary at the office of the Institute, Gresham Coltege, E.C.

THE following are among recent appointments :--Dr. Zuber, Privatdocent in Geology in Lemberg University, to be Extra ordinary Professor; Dr. Henking, Privatdocent in Zoology in Göttingen University, to be Extraordinary Professor; Dr. Oertel to be Observer in the Observatory at Munich; Dr. Ludwig Kathariner to be Professor of Zoology and Comparative Anatomy in the University of Fribourg ; Prof. Dr. Buchner to be Extraordinary Professor of Chemistry at Tuibingen; Dr. Albert Fleischmann to be Director of the Zoological Institute at Erlangen; Dr. George Rörig to be Extraordinary Professor of Zoology in Königsberg University.

Mr. James G. LAwN, Instructor in Mine Surveying at the Royal College of Science, London, has been appointed Professor of Mining at the South African School of Mines. The School was started some years ago, but it is undergoing reorganisation. It is proposed that the course of instruction shall extend over four years; the first two years-in which scientific instruction will be given-being spent at the South African College, Cape Town. The third year will be spent at Kimberley, where theoretical and practical instruction in mining will be given. The fourth year will be chiefly taken up with practical work at Johannesburg. The Cape of Good Hope University is to be asked to establish a Mining degree, the final examinations for which the students would attend at the end of their fourth year. So far only the preliminary scientific instruction has been given, and $\mathrm{Mr}$. Lawn is going out to organise and initiate the instruction to be given in the third and fourth years of the course. The salary is $£ 800$ a year.

FULL recognition is being given to the scientific attainments of women in America. We learn from Science that at Bryn Mawr College Miss F. Cook has been appointed Fellow in mathematics; Miss F. Lowwater, in physics, and Miss C. Fairbanks, in chemistry.

Science records the following gifts to education and research in America. Mrs. Lydia Bradley, of Peoria, Ill., has made known her attention of giving $1,000,000$ dols. for a polytechnic institute in Peoria.- A Boston citizen, whose name is withheld, has given 100,000 dols. to establish a chair of Comparative Pathology in the medical school of Harvard University. - Mrs. J. S. T. Stranahan, of Brooklyn, has given 5000 dols. to the building fund of Barnard College. - The Catholic University has received 5000 dols. by the will of the Rev. Father Dougherty, of Honesdale, $\mathrm{Pa}$. - It is expected that Mayor Strong will approve the Bill authorising the Board of Estimate and Apportionment to give the College of the City of New York 175,000 dols. a year instead of 150,000 dols., the amount it has received for several years.

AT the general meeting of Convocation of the University of London, held on Tuesday, it was resolved-" That some means should be devised for a more thorough preliminary investigation 